\title{
Making the GRADE: how useful are the new Surviving Sepsis Campaign guidelines?
}

\author{
Mai Vo ${ }^{1}$ and Jeremy M Kahn $n^{1,2,3^{*}}$ \\ University of Pittsburgh Department of Critical Care Medicine: Evidence-Based Medicine Journal Club, edited by Sachin Yende
}

\section{Expanded abstract}

\section{Citations}

Dellinger RP, Levy MM, Rhodes A, Annane D, Gerlach H, Opal SM, Sevransky JE, Sprung CL, Douglas IS, Jaeschke R, Osborn TM, Nunnally ME, Townsend SR, Reinhart K, Kleinpell RM, Angus DC, Deutschman CS, Machado FR, Rubenfeld GD, Webb S, Beale RJ, Vincent JL, Moreno R; Surviving Sepsis Campaign Guidelines Committee including The Pediatric Subgroup: Surviving Sepsis Campaign: international guidelines for management of severe sepsis and septic shock, 2012. Intensive Care Med 2013, 39:165-228.

Dellinger RP, Levy MM, Rhodes A, Annane D, Gerlach H, Opal SM, Sevransky JE, Sprung CL, Douglas IS, Jaeschke R, Osborn TM, Nunnally ME, Townsend SR, Reinhart K, Kleinpell RM, Angus DC, Deutschman CS, Machado FR, Rubenfeld GD, Webb SA, Beale RJ, Vincent JL, Moreno R; Surviving Sepsis Campaign Guidelines Committee including the Pediatric Subgroup: Surviving Sepsis Campaign: international guidelines for management of severe sepsis and septic shock: 2012. Critical Care Med 2013, 41:580-637.

\section{Background}

Updated guidelines are needed to guide physicians to care for patients with severe sepsis on the basis of recent advances. Whether recommendations in the guidelines published previously were based on high-quality evidence or reflected preferences of care of a set of experts was unclear.

\footnotetext{
* Correspondence: kahnjm@upmc.edu

${ }^{1}$ Department of Critical Care Medicine, University of Pittsburgh, 3550 Terrace Street, Pittsburgh, PA 15621, USA

${ }^{2}$ Clinical Research, Investigation, and Systems Modeling of Acute IIIness (CRISMA) Center, University of Pittsburgh, 3550 Terrace Street, Pittsburgh, PA 15621, USA

Full list of author information is available at the end of the article
}

\section{Methods}

Objective: The objective was to provide an update to the 'Surviving Sepsis Campaign Guidelines for Management of Severe Sepsis and Septic Shock', last published in 2008.

Design, setting, and subjects: A consensus committee of 68 international experts representing 30 international organizations was convened. The authors were advised to follow the principles of the Grading of Recommendations Assessment, Development and Evaluation (GRADE) system to guide assessment of quality of evidence from high (A) to very low (D) and to determine the strength of recommendations as strong (1) or weak (2). The potential drawbacks of making strong recommendations in the presence of low-quality evidence were emphasized.

Intervention and outcomes: None

\section{Results}

Key recommendations and suggestions in the guidelines included early quantitative resuscitation of patients with sepsis (1C); early initiation of antibiotics (1C); use of crystalloids in resuscitation (1B); use of norepinephrine as the first-choice vasopressor (1B); avoidance of intravenous steroids if hemodynamic stability can be achieved (2C); use of low tidal volumes, limited plateau pressures, and a conservative fluid strategy in acute respiratory distress syndrome $(1 \mathrm{~A}, 1 \mathrm{~B}$, and $1 \mathrm{~B})$; and minimizing continuous intravenous sedation (1B).

\section{Conclusions}

Although a number of recommendations were based on low-quality evidence, strong agreement existed among international experts regarding many level 1 recommendations as the best care for patients with sepsis. These recommendations are the foundation of improved outcomes for these patients. Using GRADE for severe sepsis guidelines will help physicians to care for these patients and provide more transparency regarding areas where 
additional evidence and individualized patient care are needed.

\section{Commentary}

Sepsis is among the leading causes of hospitalization and death worldwide [1]. As a consequence, it is imperative to undertake systematic efforts to increase the quality of sepsis care, not only to improve patient outcomes but also to reduce the financial burden of sepsis on our society. The most notable example of such an effort is the Surviving Sepsis Campaign, an international organization launched in 2002 and dedicated to enhancing evidence-based care utilization in patients with sepsis.

The centerpiece of the Surviving Sepsis Campaign is a set of clinical practice guidelines, first published in 2004. With continual innovations in sepsis care, the guidelines were updated in 2008 and again in 2012. The most recent update, published jointly in Critical Care Medicine and Intensive Care Medicine, represents an important advance in the management of hospitalized patients with sepsis $[2,3]$. One of the key strengths of the guidelines is the use of the Grading of Recommendations Assessment, Development and Evaluation (GRADE) approach to guideline development [4]. Unlike other methods for developing clinical recommendations, GRADE explicitly separates the assessment of the quality of the evidence from the ultimate strength of the recommendations. This system allows guideline developers to transparently incorporate values and preferences during the guideline development process. For example, developers are allowed to make strong recommendations when the quality of evidence is weak, or weak recommendations when the quality of evidence is strong, particularly when patient values and preferences may strongly factor into the equation. Thus, the GRADE system more closely mirrors clinical decision making at the bedside [5]. Under GRADE, the quality of evidence is systematically graded A through D by assessing study design, risk of bias, precision, consistency, and directness of evidence. Strength of the recommendation, categorized as either strong (grade 1) or weak (grade 2), is explicitly separate from the quality of evidence and takes into account costs, values, preferences, quality of evidence, treatment effects, balance between desirable and undesirable effects, and burdens of therapy.

Using this system, the Surviving Sepsis Campaign guidelines made several strong recommendations that intensivists can use as a foundation for decision making in their practice. For example, the panel emphasized the importance of early goal-directed therapy during the first 6 hours of resuscitation (grade 1C) based on both single-center clinical trials and multi-center observational studies [6]. Numerous studies support early intravenous antibiotic administration within an hour of identifying septic shock (grade 1B) and severe sepsis without septic shock (grade
1C) [7]. Based on several recent multi-center randomized controlled trials showing no clear benefit and increased mortality with starches, crystalloids are strongly recommended as the initial choice of fluid resuscitation in severe sepsis [8]. Avoiding the use of corticosteroids in the absence of shock is another strong recommendation using outcome data from a small, clinical trial demonstrating the effects of hydrocortisone in severe community-acquired pneumonia (grade 1D). These recommendations are consistent with the quality of the evidence and patient preferences toward treatment and outcomes, an assessment made possible by GRADE's transparent system for grading the clinical evidence.

At the same time, the guideline committee made several recommendations that will be more controversial. For example, the committee, supported by only one clinical trial in which the primary endpoint was not patientcentered, made a strong recommendation for using a conservative fluid strategy in patients with sepsis-induced adult respiratory distress syndrome in the absence of evidence of tissue hypoperfusion (grade 1C) [9]. The committee also recommended the use of proton pump inhibitors over histamine- 2 receptor antagonist for stress ulcer prophylaxis (grade 2C), although the emerging consensus suggests that this approach may not be helpful and may even be harmful $[10,11]$. These recommendations highlight the fact that GRADE, though transparent, is still subjective-the recommendations depend greatly on the values and preferences of the committee members. Nonetheless, the transparency of GRADE is a key asset here, as clinicians can see how the guideline committee came up with the recommendations and thus can weigh the merits of alternate decisions.

Among the limitations of the guideline is the fact that it attempts to include nearly every aspect of critical care potentially related to sepsis, perhaps losing focus in the process. The guidelines address workup of infection, initiation of antibiotics, source control, organ damage control, and general management of the critically ill patient, such as sedation, ventilator discontinuation, and nutrition. A more narrow guideline focusing only on sepsisspecific management may be more useful to clinicians. The guidelines also emphasize 'bundles' of care for sepsis resuscitation, although the evidence behind some of the bundled recommendations is not strong (that is, using central venous pressure readings to guide volume resuscitation) [12]. Already, these bundles are being turned into quality measures on which sepsis care providers will be benchmarked, even though clinicians may validly disagree with some of the recommendations.

Despite these limitations, the Surviving Sepsis Campaign guidelines represent an important advance in the management of patients with severe sepsis. Strong recommendations in the guidelines provide immediate, 
actionable guidance for emergency care providers and intensive care unit clinicians. At the same time, weak recommendations highlight areas for future research and consensus building approaches surrounding this highrisk, high-cost patient group.

\section{Recommendation}

With an understanding of GRADE, clinicians can assess the utility and trustworthiness of the new Surviving Sepsis Campaign guidelines to tailor patient care for patients with severe sepsis or septic shock.

\section{Abbreviation}

GRADE: Grading of recommendations assessment, development and evaluation.

\section{Competing interests}

The authors declare that they have no competing interests.

\section{Author details}

${ }^{1}$ Department of Critical Care Medicine, University of Pittsburgh, 3550 Terrace Street, Pittsburgh, PA 15621, USA. ${ }^{2}$ Clinical Research, Investigation, and Systems Modeling of Acute IIIness (CRISMA) Center, University of Pittsburgh, 3550 Terrace Street, Pittsburgh, PA 15621, USA. ${ }^{3}$ Department of Health Policy and Management, University of Pittsburgh Graduate School of Public Health, 130 De Soto Street, Pittsburgh, PA 15261, USA.

Published: 15 Nov 2013

\section{References}

1. HCUP Facts and Figures: Statistics on Hospital-Based Care in the United States, 2009. Rockville, MD: Healthcare Cost and Utilization Project (HCUP); 2011.

2. Dellinger RP, Levy MM, Rhodes A, Annane D, Gerlach H, Opal SM, Sevransky JE, Sprung CL, Douglas IS, Jaeschke R, Osborn TM, Nunnally ME, Townsend SR, Reinhart K, Kleinpell RM, Angus DC, Deutschman CS, Machado FR, Rubenfeld GD, Webb S, Beale RJ, Vincent IL, Moreno R, Surviving Sepsis Campaign Guidelines Committee including The Pediatric Subgroup: Surviving Sepsis Campaign: international guidelines for management of severe sepsis and septic shock, 2012. Intensive Care Med 2013, 39:165-228.

3. Dellinger RP, Levy MM, Rhodes A, Annane D, Gerlach H, Opal SM, Sevransky JE, Sprung CL, Douglas IS, Jaeschke R, Osborn TM, Nunnally ME, Townsend
SR, Reinhart K, Kleinpell RM, Angus DC, Deutschman CS, Machado FR, Rubenfeld GD, Webb SA, Beale RJ, Vincent IL, Moreno R, Surviving Sepsis Campaign Guidelines Committee including the Pediatric Subgroup: Surviving Sepsis Campaign: international guidelines for management of severe sepsis and septic shock: 2012. Crit Care Med 2013, 41:580-637.

4. Guyatt GH, Oxman AD, Vist GE, Kunz R, Falck-Ytter Y, Alonso-Coello P, Schünemann HJ, GRADE Working Group: GRADE: an emerging consensus on rating quality of evidence and strength of recommendations. BMJ 2008, 336:924-926.

5. Eddy DM: Clinical decision making: from theory to practice. Anatomy of a decision. JAMA 1990, 263:441-443.

6. Levy MM, Dellinger RP, Townsend SR, Linde-Zwirble WT, Marshall JC, Bion J, Schorr C, Artigas A, Ramsay G, Beale R, Parker MM, Gerlach H, Reinhart K, Silva E, Harvey M, Regan S, Angus DC, Surviving Sepsis Campaign: The Surviving Sepsis Campaign: results of an international guideline-based performance improvement program targeting severe sepsis. Crit Care Med 2010, 38:367-374.

7. Gaieski DF, Mikkelsen ME, Band RA, Pines JM, Massone R, Furia FF, Shofer FS, Goyal M: Impact of time to antibiotics on survival in patients with severe sepsis or septic shock in whom early goal-directed therapy was initiated in the emergency department. Crit Care Med 2010, 38:1045-1053.

8. Zarychanski R, Abou-Setta AM, Turgeon AF, Houston BL, Mclntyre L, Marshall JC, Fergusson DA: Association of hydroxyethyl starch administration with mortality and acute kidney injury in critically ill patients requiring volume resuscitation: a systematic review and meta-analysis. JAMA 2013, 309:678-688.

9. National Heart, Lung, and Blood Institute Acute Respiratory Distress Syndrome (ARDS) Clinical Trials Network, Wiedemann HP, Wheeler AP, Bernard GR, Thompson BT, Hayden D, DeBoisblanc B, Connors AF Jr, Hite $\mathrm{RD}$, Harabin AL: Comparison of two fluid-management strategies in acute lung injury. N Engl J Med 2006, 354:2564-2575.

10. Kahn JM, Doctor JN, Rubenfeld GD: Stress ulcer prophylaxis in mechanically ventilated patients: integrating evidence and judgment using a decision analysis. Intensive Care Med 2006, 32:1151-1158.

11. Howell MD, Novack V, Grgurich P, Soulliard D, Novack L, Pencina M, Talmor D: latrogenic gastric acid suppression and the risk of nosocomial Clostridium difficile infection. Arch Intern Med 2010, 170:784-790.

12. Marik $P E$, Cavallazzi R: Does the central venous pressure predict fluid responsiveness? An updated meta-analysis and a plea for some common sense. Crit Care Med 2013, 41:1774-1781.

\section{$10.1186 / \mathrm{cc} 13113$}

Cite this article as: Vo and Kahn: Making the GRADE: how useful are the new Surviving Sepsis Campaign guidelines? Critical Care 2013, 17:328 